\title{
Consumers' Perceptions Towards Private Label Brands: A Case of Private Label Brands, Produced by Kenyan Supermarkets in Nairobi County
}

\author{
TINA KEMUNTO ONTIRIA \\ Strathmore University, Nairobi Kenya \\ STELLA NYONGESA \\ Lecturer, Strathmore University, Nairobi , Kenya \\ WILLIAM OGWAGWA MOTARI \\ Research and Project Management Consultant, ZABLIM Consultants, Nairobi, Kenya
}

\begin{abstract}
Globally, leading retailers are increasingly venturing into private label that account for more than 20 per cent of their retail sales as value-seeking consumers increasingly continue to cast their brand preference nets wider. Locally, there is a substantial growth in the private labels as retailers are concerned about their store and day by day curiosity among consumers is increasing leading to demand of private label brands in different product categories. The study therefore sought out to explore consumer's perceptions, and the expected outcomes of private label branding among Kenyan supermarket. The objectives of the study were: determine final consumer's perceptions towards private label branding by Kenyan supermarket retailers; and to determine the buying process of private label brands used in Kenyan supermarket retailers. The study therefore focused on the leading five (5) supermarkets in Nairobi County. Convenience sampling technique was used to sample subjects, and location. The study adopted a descriptive research design with a target population of 135 customers and a sample of 72 respondents was selected based on the inclusion criteria. Questionnaires were the main data collection instruments). The main method to present data was frequency tables and tables. Data was analyzed to obtain descriptive statistics more especially central tendencies; mean and standard deviation. The study showed that the most important attribute in consumers' perceptions on purchasing of private label brand was 'perceived value', followed by price, packaging, advertisement, and perceived quality. The study also found differentiation as the expected outcome of private label branding. The study conclude that the name of the supermarket persuade customers to develop preference to private label brand, as is product information on the package and similar products on the shelves being important determinants for customer purchase decision. This study recommend that supermarkets should consider expanding the product categories of private label products and utilize them as a means of differentiation against the competition by investing in consumer drivers of quality, price, display and actual product contents.
\end{abstract} Keywords: Private label brand, Consumer perceptions, Traditional/National brands.

DOI: $10.7176 / \mathrm{EJBM} / 11-20-08$

Publication date:July $31^{\text {st }} 2019$

\section{INTRODUCTION}

The emergence of private-label brands is a major milestone in the history of retailing (Chakraborty, 2013). According to Hakansson (2000), there is an overabundance of different names and definitions used to describe the concept of retailer-owned brands. A few authors prefer to use words like own brands, retailer brands, wholesaler brands or distributor own brand( Bui, 2008). Private labels are the products that are distinct to a retail chain and cannot be bought at competing retailers. Sachon and Martínez-de-Albéniz, (2009). According to Baltas (1997), such brands are consumer products produced by, or on behalf of, retailers and sold under the retailers' own name or trademark through their own outlets. Hence, they are owned and branded by retailers, generating higher margins, increased control over shelf space, and give retailers greater bargaining power in the channel of distribution. As a result of their exclusiveness, they also increase store traffic and ultimately lead to customer store loyalty (Liesse, 1993; Richardson et al., 1996; Steenkamp and Dekimpe, 1997; Suh, 2005). According to Ailawadi (2008), private labels in the consumer-packaged goods industry have experienced a worldwide surge in availability and market share in recent years. They account for one of every five items sold daily in US supermarkets, drug chains, mass merchandisers, and market share in Western Europe is even larger (Kumar and Steenkamp, 2007).

In Kenya the practice of private label branding is pointing towards being a potentially lucrative growth for the retailer. Leading chains of supermarkets Nakumatt, Tusky's, Uchumi, Naivas and Ukwala have ventured into private label branding. (Gatakaa, 2014). Nakumatt supermarket pioneered and has been stocking a wide range of its own in-house branded fast moving consumer goods (FMCG) since January 2013, in an effort to give consumers a wide variety of options. The supermarket chain is setting the pace for the local retail industry by embracing the 
global trend where private brands have dominated supermarket shelves, especially in developed countries. A survey of shopping behaviour carried by Consumer Insight found out that the market share of in-store repackage sugar in Kenyan supermarkets more than doubled from 7 per cent to 18 per cent as consumers became more pricesensitive. Findings of the study showed that retailer-owned brands were set to upset traditional brand names in the near future. It is therefore necessary to establish the consumers perception towards private label branding among producing supermarkets in Kenya. There is a substantial growth in the private labels as retailers are concerned about their store and day by day curiosity among consumers is increasing which is leading to private label brands in categories like apparel, accessories among others .According to the Market Research Agency, Technopak's report (2012) on private label brands, indicates that food and grocery segment are key drivers accounting for 20$25 \%$ and at times, $40 \%$ of all categories in private labels. Margins in private labels in staples like sugar, groceries can range between $15-25 \%$.

\section{Research Problem}

A number of retailers continue to embrace the private label branding as branded alternatives in order to influence and change consumers' preference and thereby change the consumer buying patterns. Consumer attitudes and perceptions towards these brands are mainly based on the products perceived quality, price, quality compared to that of the national brands as well as the store image. The success of private label brands is therefore influenced by the strategies adopted to position them in the minds of the consumers (Martos-Partial et al., 2011). Attitude toward private label brands have been found to influence the actual purchase and the purchase intention of these brands (Burton et al., 1998; Garretson et al., 2002; Jin and Suh, 2005). Consequently, with an increased set of brands to choose from, consumers are deciding the purchase of a particular brand by weighing various factors like price, quality, and store image. Both the manufacturers' brands and private label brands are fighting to attract the consumers on these factors. In the past, lower priced private label brands were equated with lower quality products when they were first introduced (Steiner, 2004). However, in recent times, major retailers have increased the quality level of their private label brands to near or, in some cases, even better than that of the national brand leaders (Quelch and Harding, 1996). There is evidence that quality private label brands can help differentiate a retail store and create store loyalty (Corstjens et al., 2000; Sudir and Talukdar, 2004).

Although factors leading to the development of private labels have been examined extensively in western literature, this has not been fully explored in Kenya. The reviewed local studies Rotich et al, (2016), Gatakaa (2014), Ngaru (2010), and Nganga(2o12) did not critically address the consumer perceptions variables for purchase intention of private labels. For instance, studies by Gatakaa (2014) and Ngaru (2010) were narrow and suffered from conceptual gaps since they only addressed consumer purchase drivers towards private label brands and did not examine expected outcomes. The study by Rotich et al. (2016) suffered from a contextual gap since it concentrated on the effects of store branding on the brand sales performance of consumer goods in the retail stores while the focus of the current study is on consumer perceptions towards private label brands. The study by Nganga (2012) also faced methodological issues since it was a desk based study in addition to exploring a different contextual area (Baazar's). It is due to these conceptual and contextual gaps that the current study wishes to establish the attitude of Kenyan consumers towards private label branding.

\section{LITERATURE REVIEW}

Introduction of Private Label Brand

Private label brands also known as own-label brands or own brands are retailer shops or chain's exclusive trade name (Solomon et al., 2009). A private label product is defined as the only trademark, which can only be found on the packaging and sold in a specific chain of store (Hoch, 1996). Private labels are viewed differently depending on the viewer: National brand manufacturers consider private labels to be competing products; grocery stores regard them as profit and consumers see them as good alternatives to more expensive products available in the grocery store shelf(Goldsmith et al., 2010).According to the Private Labels Manufacturers' Association the private labels encompass all merchandise sold under a retail store's private label. This label can be the store's own name or a brand name created exclusively by the retailer for that store. In some cases, a store may belong to a wholesale buying group that owns labels, which are available to the members of the group. These wholesaler-owned labels are referred to as 'controlled labels' (PLMA, 2010).

Kumar and Steenkamp (2007) have presented a similar definition that the private label is any brand that is owned by the retailer or the distributor and is sold only in its own outlets. To this definition it should be noted that one retailer to another has exported strong private labels, typically based on an exclusive agreement (Kumar and Steenkamp, 2007). Lincoln and Thomassen (2009) concur by emphasizing that private label brands are retailer brands; brands that are owned, sold and distributed by the retailer. Retailers develop exclusive store brands to differentiate themselves from competitors, and persuade consumers to develop a preference for store brands in certain or possibly all product categories. Furthermore, AMA (2005) defines the private labels as brands that are owned by the product's reseller rather than its manufacturer or as a brand name or label name attached 


\section{Consumer's perceptions towards private label branding}

Consumers attitude towards price private labels are changing with time. Previously private label brands were seen as inferior, low cost, generic brands by the consumer, but currently are perceived as fully-fledged individual brands in their own right, to be evaluated alongside all other brands. A factor behind the growing success of private labels is consumers' price consciousness and consumers' feelings that the national brands are priced too high. In addition, consumers who prefer buying private label products to national brands are price seekers to whom the price of the product is the most important factor (Sinha and Batra, 1999).

When addressing consumers' perceptions towards private label brands' quality, price and quality have positive correlation in the consumers' minds: as the price of the product increases accordingly grows the consumers' perception about the quality of the private label brands (DelVecchio, 2001). According to Cunning, Hardy and Imperial (2002), consumers rate private brands as inferior national brands in terms of taste, appearance and labeling, among other factors; while some shoppers would avoid buying them regardless of savings. However, consumers may make their purchase decisions based on the product positioning and pricing. This is mainly due to low quality image portrayed by the private brands compared to the national brands. A focus on quality could give private brands a competitive advantage in terms of favourable perception of the store brands and in turn increase consumers' towards these products, which are only available at the store chains

\section{Expected outcomes of engaging in private label branding}

Oliver (1997) posits that customer loyalty is a multidimensional construct, consisting of four dimensions: cognitive, affective, conative, and action loyalties. Firms, which achieve the highest level of loyalty, action loyalty, have customers who will overcome obstacles to patronize them. As one British retailer manager put: "customer loyalty is a fundamental reason for having own-brands" cited in Steenkamp and Dekimpe (1997). In the context of a retailer own-brand, customer loyalty encompasses two associated loyalties - brand and store loyalties. Brand loyalty to a retailer own-brand is only possible if the own-brand possesses a favorable image (Steenkamp and Dekimpe, 1997). The exclusivity of a retailer own-brand's assists in building store loyalty and decreases storeswitching behavior because store brands are store specific (Corstjens and Corstjens, 1995).

Therefore, offering exclusive products is considered as one viable strategy to build store loyalty. A growing body of literature links store loyalty to purchase of and satisfaction with store brands. Binninger (2008) finds store brand loyalty not only leads to store loyalty but also mediates the positive relationship between consumer satisfaction and store loyalty. Preference for high-quality premium own-brands further contributes to store loyalty. Two studies (Carpenter and Fairhurst, 2005; Veloutsou et al., 2004) find that customer loyalty occurs when consumers are satisfied with retail brands. In addition, we argue that retail own-brands with distinctive product advantages, such as innovative features or functions, can produce a magnetic effect that induces consumers' psychological commitment to the store, thus can be a source of store loyalty. The aforementioned studies posit that store loyalty is an outcome of satisfaction with store brands. However, a recent study (de Wulf et al., 2005) identified a "reverse effect." That is, store loyalty moderates perceived brand equity of store brands; thus loyal customers tend to purchase store brands. We acknowledge that further investigation of the reverse effect is warranted. Nevertheless, because the literature supports the former relationship: store loyalty is an outcome of satisfaction with store brands, we posit brand loyalty and store loyalty as consequences of retailer own-brand product advantage.

The second expected outcome is own- brand performance which consists of the financial benefits own-brand products bring to retailers, such as profitability and market share. A brand's performance is positively associated with its product quality (Aaker et al., 2004). Keller (1993) agrees that the gross margin of retailer own-brands can be 20-50 percent higher than national brands. Higher sales of higher margin own-brands increase profits (Richardson et al., 1994).

Technology complexity may represent another entry barrier for a retailer own-brand due to the fact that a manufacturer is usually a specialist in a few focused categories (Corstjens and Corstjens, 1995). Categories vary with level of technological sophistication. For example, in categories such as canned and frozen fruits and vegetables, processing sophistication is low, whereas in categories such as digital cameras, technology complexity is high. Hoch and Banegi (1993) find that in the categories where technological barriers are high, the comparative quality of store brands are relatively low. Thus, in categories where national brands have strength in technological innovation, a retailer may want to avoid the introduction of a premium own-brand.

Competitive intensity defined as the degree of competitive strength in retailing. As Kohli and Jaworski (1990) observe, in the absence of competition, a retailer may perform well, even if there is not much differentiation between competitors, because consumers have few options. By contrast, under conditions of high competition, consumers have many alternative options to satisfy their needs and wants. As a result, a retailer may be pressured to differentiate. The exclusivity provided by retailer own-brands has become an important differentiating strategy for retailers (Corstjens and Corstjens, 1995). However, an own-brand that mimics a leading national brand will not serve as differentiator for the retailer because the packaging, design, and quality of these own-brands may be 
too similar to national brands. On the contrary, a premium own-brand with higher quality or other innovative features will serve as differentiating factors, bringing high-profit margin for the retailer.

\section{METHODS}

The study adopted a descriptive case study research design. Five leading supermarkets (Nakumatt, Tuskys, Uchumi, Naivas \& Ukwala) which produce their own products and sell them in their own store, in Nairobi, Kenya were selected as the research context. The target population for this study was consumers that shop at the 5 leading supermarkets men or women aged 18 years old and above as well as had consumed private label product purchased from the supermarket. Five customers were randomly selected from 6 branches of each supermarket. Convenience sampling was used to sample subject and location, which allowed a large number of respondents to be interviewed in a short period of time, so it is fast and easily accessible (Hair et al., 2008). The study adopted structured questionnaire as the main data collection instrument. The questionnaire consisted of three sections, using a 5-point Likert scale for most of the questions. Questions on demographic profile of consumers i.e gender, age, education level, family size, preferred choice of supermarket were included in section A. Section B contained questions regarding consumers perceptions i.e perceived price, packaging, advertisement, perceived quality, perceived value. In section $\mathrm{C}$ consumers rated expected outcome attributes i.e customer loyalty, store loyalty, differentiation, profitability and market share. The specific questions in the questionnaire were scaled using Likert Scale $(1=\mathrm{SD}$ Strongly Disagree, 2=D-Disagree, 3=NS-Not Sure, 4=A-Agree and 5=SA-Strongly Agree) in measuring respondents level of agreement on each item of the questionnaire. Data was analyzed using descriptive statistics more especially central tendencies; mean and standard deviation. The results are therefore as analyzed, presented and discussed below.

\section{RESULTS \& DISCUSSION}

Table 1. Demographic profile of customers

\begin{tabular}{|c|c|c|c|}
\hline Demographic Variables & Classification & Frequency & Percent (\%) \\
\hline \multirow[t]{3}{*}{ Gender } & Male & 22 & 52.4 \\
\hline & Female & 20 & 47.6 \\
\hline & Total & 42 & 100.0 \\
\hline \multirow[t]{4}{*}{ Age } & $18-25$ & 12 & 28.6 \\
\hline & $26-35$ & 18 & 42.9 \\
\hline & $36-45$ & 8 & 19.0 \\
\hline & $46-55$ & 4 & 9.5 \\
\hline \multirow[t]{3}{*}{ Educational qualifications } & Primary & - & - \\
\hline & Secondary & 10 & 23.8 \\
\hline & Tertiary & 32 & 76.2 \\
\hline \multirow[t]{4}{*}{ Family size } & Alone & 0 & 0 \\
\hline & $<5$ & 40 & 95.2 \\
\hline & $5-10$ & 2 & 4.8 \\
\hline & $>10$ & - & - \\
\hline \multirow[t]{5}{*}{ Choice of supermarket } & Nakumatt & 16 & 38.1 \\
\hline & Tusky's & 12 & 28.6 \\
\hline & Uchumi & 4 & 9.5 \\
\hline & Naivas & 8 & 19.0 \\
\hline & Ukwala & 2 & 4.8 \\
\hline \multirow{4}{*}{$\begin{array}{l}\text { How long been } \\
\text { purchasing from the } \\
\text { supermarket }\end{array}$} & $<5$ & 20 & 47.6 \\
\hline & $6-10$ & 16 & 38.1 \\
\hline & $11-15$ & 2 & 4.8 \\
\hline & $>15$ & 4 & 9.5 \\
\hline \multirow[t]{5}{*}{ Private labels purchased } & Consumables & 23 & 54.8 \\
\hline & Detergents & 7 & 16.7 \\
\hline & Cereals & 4 & 9.5 \\
\hline & Toiletries & 6 & 14.3 \\
\hline & Others & 2 & 4.7 \\
\hline
\end{tabular}

\section{Source: Survey data (2016)}

Table 4.1 shows that the majority of the respondents were aged between 26 and 35 years old (42.9\%). There was a near balance of equal representation on gender, male respondents accounted for 52 percent and female 48 percent of the total number of respondents. Most respondents had qualifications to Tertiary level (76.2 \%) and were having a family size of less than five household persons $(95.2 \%)$. Majority of the respondents who 
participated in this study have been purchasing from their preferred supermarket, with Nakumatt supermarket the most preferred (38.1\%), followed by Tuskys (28.6\%), Naivas (19\%), Uchumi $(9.5 \%)$ and Ukwala (4.8\%). Nearly half of the respondents $(47.1 \%)$ have been purchasing from the supermarket for less than 5 years and consumables $(54.8 \%)$ topped the list of private label goods purchased. Others specified water, ready to eat snacks, detergents and clothes.

This findings are in congruent to the Market Research Agency, Technopak's report (2012) on Private Label 2012 whose findings reported that food and grocery segment were key drivers for Private label brands accounting for $20-25 \%$ and at times, $40 \%$ of all categories in Private Labels. Further, this findings are congruent with Gatakaa(2014) who found out that although Nakumatt is the biggest supermarket retail by market, the supermarket chain is a pace setter for the local retail industry by embracing the global trend where private brands have dominated supermarket shelves, especially in developed countries. Tusky's, Uchumi and Naivas are among other supermarkets that have ventured into private label branding.

\subsection{Customers Perceptions towards private label brands}

First an understanding was sought on consumers understanding of private label brands by identifying the activities performed by supermarkets leading to private label brands.

\section{Table 2: Activities performed by supermarkets leading to private labels}

\begin{tabular}{|l|c|c|}
\hline Measurement items & Mean & $\begin{array}{l}\text { Std. } \\
\text { Deviation }\end{array}$ \\
\hline $\begin{array}{l}\text { Goods produced/sold that are distinct to this supermarket and cannot be } \\
\text { bought at competing supermarkets. }\end{array}$ & 3.33 & 1.337 \\
\hline $\begin{array}{l}\text { Goods produced/packaged in the name of the supermarket which deliver } \\
\text { a quality customer experience }\end{array}$ & 3.86 & .899 \\
\hline $\begin{array}{l}\text { Goods produced/packaged in the name of the supermarket which are } \\
\text { lowly priced }\end{array}$ & 4.14 & .843 \\
\hline
\end{tabular}

The specific questions concerning activities performed by supermarkets leading to private label branding were scaled using Likert Scale (1=SD-Strongly Disagree, 2=D-Disagree, 3=NS-Not Sure, 4=A-Agree and 5=SAStrongly Agree) in measuring respondents level of agreement on each item of the questionnaire.

Source: Survey data (2016)

Based on the descriptive data in Table 4.2, respondents were in agreement that goods packaged in the name of the supermarket $(M=4.14$ S.D. $=0.843)$ is the most dominant activity in consumers mind in identifying a private label product, followed by a perception that the same goods deliver a quality experience $(\mathrm{M}=3.86$ S.D. $=0.899)$ and that the same goods in the name of the supermarket persuade customers to develop preference to them $(\mathrm{M}=3.33$ S.D. $=1.337$ ). There are greater variation among responses (S.D. $=1.337$ ) in regard to good packaged in the name of the supermarket persuade customers to develop preference to them. The findings reveal that supermarkets are increasingly using private label brands as a means to differentiate themselves from competitors. In addition to standard flagship private labels that bear firm names, supermarkets are offering more premium and food brands, such as line of drinking water and clothing. These premium private labels serve not only to distinguish supermarket chains' product lines from one another but also to place national brands and private labels more directly in price and quality competition. 
Table 3: Descriptive data of customer's perceptions variables of private label brands

\begin{tabular}{|c|c|c|}
\hline Measurement items & Mean & $\begin{array}{l}\text { Std. } \\
\text { Deviation }\end{array}$ \\
\hline \multicolumn{3}{|l|}{ PERCEIVED PRICE } \\
\hline I compare prices of other brands and private label and choose one & 3.90 & .932 \\
\hline The price of the private label is reasonable for me & 4.14 & .647 \\
\hline I can save lots of money buying private label products & 4.14 & .718 \\
\hline I buy private label food products because they are cheap & 3.43 & 1.382 \\
\hline Overall perceived price & 3.90 & 0.9198 \\
\hline \multicolumn{3}{|l|}{ PACKAGING } \\
\hline I like to buy the product that has attractive packaging & 3.76 & .821 \\
\hline I think the packaging of private label food products is similar to other products & 4.71 & .997 \\
\hline Actual product contents(ingredients) are displayed on private label products & 3.00 & 1.169 \\
\hline Overall packaging & 3.82 & 0.996 \\
\hline \multicolumn{3}{|l|}{ ADVERTISEMENT } \\
\hline My decision to purchase is influenced by advertisement & 2.67 & 1.183 \\
\hline The message on the advertisement attempts to persuade me to buy private label & 2.90 & 1.031 \\
\hline I trust on the message given by the advertisement & 2.95 & .854 \\
\hline Overall advertisement & 2.84 & 1.022 \\
\hline \multicolumn{3}{|l|}{ PERCEIVED QUALITY } \\
\hline I think private label products are of better quality than national brands & 3.43 & 1.063 \\
\hline \multicolumn{3}{|l|}{ PERCEIVED VALUE } \\
\hline When I buy the private label product I ensure that I am getting my money's worth & 4.19 & .505 \\
\hline $\begin{array}{l}\text { I always check the prices at the supermarket among brands to ensure I acquire the best } \\
\text { value for money product }\end{array}$ & 3.95 & 1.058 \\
\hline Overall Perceived Quality & 4.07 & 0.782 \\
\hline
\end{tabular}

The specific questions concerning customers perceptions of private label branding were scaled using Likert Scale (1=SD-Strongly Disagree, 2=D-Disagree, 3=NS-Not Sure, 4=A-Agree and 5=SA-Strongly Agree) in measuring respondents level of agreement on each item of the questionnaire.

Table 4.3 indicate that respondents were in strong agreement that perceived value $(M=4.07, \mathrm{~S} . \mathrm{D}=0.782)$ is the most important variable in consumers' perceptions on purchasing of private label brands, followed by perceived price $(M=3.90, S . D .=0.9198)$, packaging $(M=3.82$, S.D. $=0.996)$, perceived quality $(M=3.43$, S.D. $=1.063)$ and advertisement $(\mathrm{M}=2.84, \mathrm{~S} . \mathrm{D} .=1.022)$. Further, packaging of private label food products in a similar manner to other products $(\mathrm{M}=4.71, \mathrm{~S} . \mathrm{D} .=0.997)$ and affordability of price $(\mathrm{M}=4.14$, S.D. $=0.647)$ were dominant judgment attributes among the categories. The variation among responses were greater in respect to perceived advertisement(S.D.=1.022) and specific attributes of buying private label food products because they are cheap( S.D.=1.382) and that actual product contents(ingredients) are displayed on private label products (S.D. $=1.169)$

This finding indicates that most consumers are value sensitive and that they will ensure getting the best value during the purchasing process for private label products equally as national/ traditional brands. In addition they are willing to pay if the perceived value of the product has a higher quality, informative and low in price. These findings are congruent with Chen (2008), who reported that consumer's willingness to purchase private label was driven by high quality, attractive attributes and lowly priced. Further, this study indicate that consumers prefer to buy private label products mainly due to their low price and prefer to buy products from large chain of retailers which also offer a wide variety of private label products with better quality.

Although in the past, lower priced private label brands were equated with lower quality products when they were first introduced (Steiner, 2004), the findings of this study report that consumers today acquire more information about the product, especially when there are similar quality products in the retail shelves being in congruent with Chen (2008) who found that the more the product information, the more likely consumers are willing to purchase because it reduces purchase risk.

The study also found that consumers were more price sensitive to the extent of making comparisons of prices among other brands and private labels $(M=3.90$ S.D. $=0.832)$. This is perhaps so because of increasing cost of living, including fuel prices, utility rates and unemployment resulting in a reduction of consumer's disposable income and affecting their purchasing power. A less important variables influencing purchase of private label product is packaging characteristics and advertisement. Most of the respondents reported that they are influenced by a package which is similar to other national products brands but not on the actual product contents (ingredients) displayed on the pack which is incongruent with (Munusany and Wong, 2008; Semeijin et al, 2004) who found that an attractive package of a private label product create a favorable image and perception to influence consumer 
purchase

4.4 Expected outcomes of private label branding among Kenyan Supermarkets Table 4: Expected outcomes of private label branding attributes

\begin{tabular}{|c|c|c|}
\hline Measurement items & Mean & $\begin{array}{l}\text { Std. } \\
\text { Deviation }\end{array}$ \\
\hline \multicolumn{3}{|l|}{ Customer Loyalty } \\
\hline Private Label brands will present our customers with a variety of products & 4.41 & .618 \\
\hline Private label brands will help develop a relationships with our customers & 4.18 & 1.015 \\
\hline Our products will reach more customers & 4.29 & .772 \\
\hline Overall customer loyalty & 4.29 & .802 \\
\hline \multicolumn{3}{|l|}{ Store loyalty } \\
\hline Private Label brands will increase customer's loyalty to our store & 4.29 & .588 \\
\hline Private label brands reinforce the store image & 3.59 & 1.278 \\
\hline Our supermarket will obtain control over shelf space and stocks & 3.94 & .827 \\
\hline $\begin{array}{l}\text { Private label products will lessen our dependence on the store to national branded } \\
\text { products. }\end{array}$ & 3.65 & 1.115 \\
\hline Overall store loyalty & 3.87 & .952 \\
\hline \multicolumn{3}{|l|}{ Profitability and Market share } \\
\hline Private label brands will be less influenced by crisis in the market & 3.53 & .800 \\
\hline Private label brands will allow our customers to buy products with lower prices & 4.24 & .970 \\
\hline Private label brands will increase profit margins in our product categories & 3.59 & 1.121 \\
\hline Private label brands will increase our store's profitability & 4.24 & .903 \\
\hline Private label brands will increase our market share & 4.47 & .800 \\
\hline Overall profitability and market share & 4.014 & .9188 \\
\hline \multicolumn{3}{|l|}{ Differentiation } \\
\hline Our supermarket will get a different place in the market than rivals & 4.24 & .970 \\
\hline Private label brands will support our effort of developing new products & 4.12 & .993 \\
\hline $\begin{array}{l}\text { Private label products will increase our competitiveness against national branded } \\
\text { products }\end{array}$ & 3.94 & .966 \\
\hline Our products will force rivals to reduce their pricing & 3.53 & .874 \\
\hline Private label products will provide a cost advantage to our supermarket stores & 3.88 & .857 \\
\hline Private label products will differentiate our product from other stores & 4.65 & .493 \\
\hline $\begin{array}{l}\text { Private label products will create a special target market for our stores by focusing on } \\
\text { a certain consumer group }\end{array}$ & 3.88 & 1.269 \\
\hline Overall differentiation & 4.03 & 0.642 \\
\hline
\end{tabular}

The specific questions concerning expected outcomes of private label branding were scaled using Likert Scale (1=SD-Strongly Disagree, 2=D-Disagree, 3=NS-Not Sure, 4=A-Agree and 5=SA-Strongly Agree) in measuring respondents level of agreement on each item of the questionnaire.

Table 4.4 reveal that respondents strongly agreed that customer loyalty $(\mathrm{M}=4.01, \mathrm{~S} . \mathrm{D}=.919)$ is the most pronounced outcome of private label branding, followed by profitability and market share $(\mathrm{M}=4.01, \mathrm{~S} . \mathrm{D} .=0.919)$, differentiation $(\mathrm{M}=4.03$, S.D. $=0.642)$ and store loyalty $(\mathrm{M}=3.87, \mathrm{~S} . \mathrm{D}=.952)$. In specific there was a very strong agreement among respondents that Private label brands will increase supermarkets market share $(\mathrm{M}=4.47)$ with the variation among the responses being the least $(S . D=.800)$ in comparison to other attributes.

The findings of this study indicate that a key benefit for supermarkets owning a brand is that it enables them to reap a higher profit margin than they would on other brands while selling the goods at a lower price to consumers. This is perhaps so, because the private labels are benchmarked, against leading brands in the respective categories, but also in most cases priced below their counterparts to entice shoppers. Although a growing body of literature links store loyalty to purchase of and satisfaction with store brands (Carpenter and Fairhurst, 2005; Veloutsou et al., 2004), this study, found an incongruent or otherwise view that private label brands will increase customer's loyalty to our store $(\mathrm{M}=4.29, \mathrm{~S} . \mathrm{D}=0.588)$ up holding the view that, store loyalty moderates perceived brand equity of store brands; thus loyal customers tend to purchase store brands.

This study found out that private label brands reinforce the store image concurring with Binninger (2008) study who found that store brand loyalty not only leads to store loyalty but also mediates the positive relationship between consumer satisfaction and store loyalty. Private label brands are a win-win situation for retailers and customers since in the eventuality; profitability is increased followed by store loyalty to the retailer. From an economic point of view, retailers can sustain in business during market slump as their products can be offered at lesser price (during recession) and thus act as shield to retailer. 
This study found that the exclusivity provided by retailer own-brands is an important differentiating strategy for supermarkets concurring with Corstjens and Corstjens (1995). Although, this study did not establish that private label brands that mimic leading national brand serve as differentiator for the retailer as a result of packaging, design, and/or quality of these brands being similar to national brands, it found that, a premium own-brand with higher quality or other innovative features will serve as differentiating factors, resulting to a high-profit margin for the retailer. These findings are congruent with (Corstjens et al 2000; Sudir and Talukdar, 2004) who held the view that quality private label brands can help differentiate a retail store and create store loyalty.

\section{CONCLUSIONS AND RECOMMEDATIONS}

This study found that that goods packaged in the name of the supermarket was the most dominant activity in consumers mind in identifying a private label product, and conclude that the name of the supermarket persuade customers to develop preference to them. Further, the study conclude that 'perceived value' becomes the most important attribute in consumers' perceptions on purchasing of private label brands, followed by other factors, that is perceived price, packaging, advertisement, perceived quality among others. The result of this study also show that the purchasing of a private label brand is insignificantly influenced by advertisement and conclude that product information on the package and similar products on the shelves are important determinants for customer purchase decision.

This study found out that differentiation was the most dominant expected outcome of private label branding among Kenyan supermarkets. Others were profitability and market share, customer loyalty, store loyalty among others and conclude that private label branding by supermarkets results in getting a different place in the market than rivals as the Private label products differentiate the supermarket product from other stores.

The study therefore recommends that;

1. Supermarkets should consider expanding the product categories for private labels beyond non-food products including apparel and accessories.

2. Supermarkets should put more investment on the key findings of this study to make private label branding of consumer and non-consumer goods part of their operations. The supermarkets therefore should pay more attention to 'perceived value' and also use the brands differentiation as a means of gaining market share and increasing retailing profitability.

3. The supermarkets should operationalize the concept of private label branding by making it a department with full budget, human resources and merchandizing so that it may be a fully evolving branding concept in the knowledge body of marketing.

\section{REFERENCES}

Hoch, S.J. (1996). How should National brands think about Private Labels? Sloan Management Review Vol. 37(12). Pp.89-102

Aaker,J. L., Fournier, S.M., and Brasel, S.A (2004).When good brands do bad. Journal of Consumer Research, Vol(31) pp. 1-16.

Ailawadi, K. L. and Harlam. B., (2008). An empirical analysis of the determinants of retail margins: the role of store-brand share. Journal of Marketing, 68(1), 147-165

American Marketing Association. (2005). Dictionary of private label product: [Online]. Available athttp://www.marketingpower.com/mg-dictionary.php Retrieved February 28, 2016

Baltas, G.(1997)Determinants of store brand choice: A behavioral analysis, Journal of Product and Brand Management. 6(5), $315-324$

Binninger, A.S. (2008). Exploring the relationships between retail brands and consumer store loyalty. International Journal of Retail \& Distribution Management, 36(2), 94-110.

Bui, M. H. (2008). Private Label Competition:The perspective of Swedish Branded Goods Manufacturers. Management Research News , 31 (2), 125-141.

Burton, S., Lichteenstein, D.Netemeyer, R.and Garretson, J.(1998). A scale for measuring attitude towars private label product and an examination of its physchological and behavioral correlates. Academy of Marketing Sciences. Vol 8(3) pp 196-210

Chakraborty, S. (2013). Private Lable Brands- A literature review. SIT Journal of Management , 3, 75-88.

Carpenter, J., \& Fairhust, A. (2005).Consumer shopping value, satisfaction, and loyalty for retail apparel brands. Journal of Fashion Marketing \& Management , 9 (3), 256-69

Chen, K..C ( 2008) A study of the relationship between UK consumers' and store brand food products. Unpublished Masters Dissertation. The University of Nottingham

Corstjens, J., and Corstjens, M (1995). Store Wars: The Battle for Mindspace and Shelfspace. Chichester: J. Wiley.

Corstjens M., and Lal R., (2000). Building store loyalty through store brands, Journal of Marketing Research, vol. 37, iss. 3.

Ngaru, M. (2010) An exploratory Study on Consumer Purchase drivers towards private label brands: A case of 
Nakumatt Supermarkets. Unpublished Master's Thesis, Strathmore University, Kenya.

Hair, J.F., Wolfinbarger, M., Ortirau, D.J and Bush, R.P. (2008). Essentials of marketing research, New York, Prentice Hall.

Hakansson, P.(2000) Beyond Private Label- The strategic view on distributor own brands. Ph.D Thesis, Stockholm: EFI Stockholm School of Economics.

Hoch, S. (1996). How should national brands think about private labels? Sloan Management Review , 37 (2), 89 102.

Hoch, S., and Banegi, S. (1993). When do private labels succceed? Sloan Management Review, 34 (4), 57-67.

Keller, K.L.(2003) Strategic Brand Management: building, measuring and managing brand equity. Upper-Saddle River, Prentice Hall.

Kohli, T. L. (2013). The comparative influence of manufacaturer and retailer brnads on customers' purchase behaviour. Journal of Product and Brand Management , 22 (3), 208-217.

Kumar, N. and SteenKamp,J. B.E.M (2007). Private Label Strategy. How to meet the store brand Challenge. Harvard Business School Press ANSI Z (39) pp 48-92

Munusany,J.and Wong, C.H (2008). Relationship between marketing mix strategy and consumer motive: an empirical study in major Tesco stores. UNITARE E-Jounal. Vol.4(2).

Nganga, W.N. (2012). Factors affecting the success of private label Bread brands of large car motorbaazars in Nairobi, Kenya.

Quelch, J., \& Harding, D. (1996). 1996. Harvard Business Review , 74 (1), 99-110.

Richardson, P., Jain, A.K., and Dick, A.S (1994). The influence of store aesthetics on the evaluation of private label brands. Journal of product and Brand Management. Vol.5(1), pp.19-28

Richardson, P., Jain, A.K., and Dick, A.S (1994). Household store brand proneness: a framework: Journal of retailing. Vol.72(2), pp.159-185

Rotich,J., Moriasi,K.J., Korir,C.S., Rono, K.E and Asienyo, B.O (2016). Effect of Store Branding on the Brands Sales Performance of Consumer Goods in the Retail Stores in Nakuru Town, Kenya. International Journal of Innovation and Applied Studies. Vol14(3) 875-885 [ Online].Available http://www.ijias.issr-journals.org/. ( Accessed February 14, 2016)

Solomon, M.R., Stephene, D., Susan, d.,and Bennett, R.R.,(2007) Consumer behavior buying, having, and being.Australia.

Semeijin,J., Van Riel, A.C.R., Ambrosini, A.B(2004) Consumer evaluations of store brands: Effects of store image and product attributes. Journal of Retailing and Consumer Service. Vol 11(4) pp247-258[Online]: Accessed December 12, 2015

Sudhir, K and Talukdar, D (2004) Does store brand patronage improve store patronage? Review of Industry Organization. Vol 24(2). PP 143-160 